\title{
Music value and participation: An Australian case study of music provision and support in Early Childhood Education ${ }^{1}$
}

\section{Margaret Barrett}

The University of Queensland, Australia

\section{Libby Maree Flynn}

The University of Queensland, Australia

\section{Graham Welch}

University College London, United Kingdom

\begin{abstract}
There is a growing body of evidence that early engagement in active music-making impacts beneficially on children's wider development. Recent research indicates that individual and shared music-making in family settings contributes to positive parenting practices and identity development in young children. Children who participate in shared music-making at age 3 are better prepared for school experiences at age 5 . These findings suggest music should be a compulsory requirement in any early childhood programme. This article reports the findings of a case study investigation of the provision of music in an Australian Early Childhood Education Centre. Findings suggest that music provision is best supported when there is a high value for music amongst staff, there is a range of value-added as well as integrated uses of music, and there is sustained music professional development for all staff.
\end{abstract}

\section{Keywords}

early childhood education, music development, music early learning, music participation, provision

\section{Introduction}

There is a growing body of evidence that early engagement in active music-making impacts beneficially on children's development, including: aural perception and language skills (Putkinen, Tervaniemi, \& Huotilainnen, 2013; Williams, Barrett, Welch, Abad, \& Broughton, 2015); reading (Long, 2014; Gordon, Fehd, McCandliss, 2015); verbal memory (Roden, Grube,

\footnotetext{
${ }^{1}$ Published in Research Studies in Music Education, Online 22 June 2018

DOI: $10.1177 / 1321103 \times 18773098$
} 
Bongard, \& Kreutz, 2014); spatial reasoning (Hetland, 2000); self-regulation (Winsler, Ducenne, \& Koury, 2011); pro-social skills (Williams et al., 2015); and general school attainment (Wetter, Koerner, \& Schwaninger, 2009). Arts-enriched preschool environments that include music improve children's school readiness and receptive vocabulary (Brown, Benedett, \& Armistead, 2010), literacy (Phillips, Gorton, Pinciotti, \& Sachdev, 2010), cognitive reasoning (Portowitz, Lichtenstein, Egorova, \& Brand, 2009) and emotional regulation skills, including for children from low-income families at risk (Brown \& Sax, 2013). Such advantages have been documented in studies that have controlled for socio-economic status. A key factor in such studies is music-making that is active (singing and playing instruments), involves generative opportunities (composing and improvising), whether undertaken in groups/individually, and is a "fun" positive experience for the children (cf. Barrett, 2012; Hallam, 2015).

Recent research indicates that individual and shared music-making in family settings contributes to positive parenting practices (Barrett, 2009) and identity development in young children (Barrett, 2011, 2016a, 2016b). A large-scale Australian study suggested that children who participate in shared music-making at age 3 are better prepared for school experiences at age 5 (Williams et al., 2015).

Given the evidence, there is a strong case for music to be an essential element in any early childhood (0-5) programme. This article provides an overview of recent developments in early childhood policy and practice in Australia to contextualise an illustrative detailed case study analysis of music provision within one community-based Early Childhood Education Centre, including those factors that facilitate and constrain provision.

\section{Setting the Policy Context}

Internationally, there has been increasing recognition of the importance of early years education as well as the value of arts education for all children. For example, the UK's Cultural Learning Alliance (2017) recently updated its earlier (2011) findings on the positive impact of arts education, using only evidence from cohort studies with large sample sizes (typically 12,000), and research with control groups. Amongst the key findings, drawn from studies in the UK, USA and elsewhere, was that participation in structured arts activities can increase cognitive abilities by $17 \%$, including improving attainment in mathematics and English. In particular, students from low-income families who take part in arts activities in school were reported to be three times more likely to obtain a degree. One possible explanation for such impact relates to the involvement of the family in children's musical learning (McPherson, 2009; Williams et al., 2015).

Another related explanation concerning arts impact involves neuroplasticity-how the brain responds to, and is changed by, experience. A recent OECD (Ansari, König, Leask, \& Tokuhama-Espinosa, 2017) review of pedagogical knowledge, for example, argues that research in developmental cognitive neuroscience offers useful explanations of key properties of the brain (such as experience-dependent-neuroplasticity), as well as the 
mechanisms underlying the transfer of knowledge from one domain to another (Ansari et al., 2017). The OECD authors argue that teaching will be enriched if practitioners understand more about the neuronal basis for learning. Relatedly, a UK Government-funded study of good practice in early years education - part of a major longitudinal study of 6,000 children across England from the age of 2-has reported on how effective early years provision builds upon statutory requirements (including in the expressive arts) through effective communication and engagement with parents, such as in supporting transitions between home and school and also in encouraging home learning (Callanan, Anderson, Haywood, Hudson, \& Speight, 2017).

In keeping with these developments internationally, the Australian Early Childhood sector is experiencing significant policy and practice change, embracing a National Quality Agenda for Early Childhood Education and Care since 2012 (Council of Australian Governments, n.d.). ${ }^{1}$ Significant earlier developments in the change process included the development and implementation of the first national framework for early childhood education, Belonging, Being \& Becoming; The Early Years Learning Framework (EYLF) (Department of Education, Employment and Workplace Relations (DEEWR), 2009). In the introduction to the EYLF Educators' Guide, it is made clear that the document is "a framework of principles, practices and outcomes with which to build your curriculum ... not a syllabus, not a program, not a curriculum, not a model, not an assessment tool, not a detailed description of everything children will learn" (DEEWR, 2010, p. 3). Rather, the EYLF provides structure and observable targets for educators, placing children's play-based learning at its core through the use of sensory, creative, physical, symbolic, projective, dramatic and role play, and games with rules. The document outlined five learning outcomes for children aged from birth to 5 years:

- Children have a strong sense of identity;

- Children are connected with and contribute to their world;

- Children have a strong sense of well-being;

- Children are confident and involved learners; and

- Children are effective communicators. (DEEWR, 2009, p. 8)

Music is mentioned sparingly in the document, with limited guidance on the inclusion of music in children's early learning experiences. Despite the emerging body of evidence on the role of music in children's identity (Barrett, 2011, 2016a, 2016b), their capacity to connect with and contribute to their world through musical engagement (cf., Nyland, Acker, Ferris, \& Deans, 2015), and the impact of music engagement on learning behaviours and outcomes (see introduction), music is only mentioned as a mode of communication (outcome 5), and as an ancillary activity in promoting children's health and well-being (outcome 3 ).

In a study of one teacher's music-making in an Australian Childcare Centre, deVries (2005, 2006) noted that despite participation in researcher-led Professional Development (PD), the teacher was unable to implement a comprehensive developmental music programme. Such findings point to persistent unevenness of provision in Australian music education. These include reports on inadequate music provision in Early Childhood and Primary (ECP) teacher education - an average of 17 hours of music education across their degree (Letts, 2015) and little acknowledgement in professional policy and practice for Early Childhood Education 
(ECE) workers (DEEWR, 2009; Suthers, 2008; Nyland et al., 2015). Research indicates that teachers' pre-service education informs their practice and personal philosophies of childhood education (Garvis, 2012); further, there is an international and longstanding research literature that suggests poor preparation leads to limited confidence in presenting music experiences and fears of losing control (Bainger, 2010; Ballantyne \& Packer, 2004; Hennessy, 2000; Kim \& Kemple, 2011; Mills, 1989; Stunell, 2006; Welch \& Henley, 2014).

In the absence of national guidance or music curriculum for the 0-5 ECE sector, the provision of music education is at the discretion of individual Centres (Nyland et al., 2015; Suthers, 2004, 2008). Considering the above, we are led to ask, where or how will educators acquire the necessary knowledge and skills to implement music in their classroom?

The National Quality Framework Snapshot for Quarter 2, 2016 (Australian Children's Education and Care Quality Authority (ACECQA), 2016) identified 15,417 child-care services across Australia (14,317 centre-based Early Childhood Education, 1100 family day-care). The quality rating of these services is in progress, with some 12,286 assessed thus far against the following five-level benchmark:

1. Significant improvement required;

2. Working towards National Quality Standard;

3. Meeting National Quality Standard;

4. Exceeding National Quality Standard; and

5. Excellent.

Centres are assessed across seven areas, those of:

- Educational programme and practice;

- Children's health and safety;

- Physical environment;

- Staffing arrangements;

- Relationships with children;

- Collaborative partnerships with families and communities; and

- Leadership and service management.

Of those centres assessed, $30 \%$ are yet to meet the Standards requirements (ratings 1 and 2). Non-compliance ranges from $61 \%$ in the Northern Territory to $20 \%$ in Victoria. Significantly, only $n=49(0.4 \%)$ of registered providers across the country were rated excellent (rating 5), with $29 \%$ rated as exceeding the National Quality Standards (rating 4). Those Standards in which Early Childhood Education provision was least adequate related to the Educational Program and Practice.

Given these figures, it is likely that music provision in Early Childhood Education is also limited and of variable quality. This paper investigates those factors that facilitate and constrain the provision of music experiences in Early Childhood Education through a case study analysis of an Australian Early Childhood Education Centre. 


\section{Methodology}

This case study investigation sits as one strand within a national study of music early learning and development in Australian families. ${ }^{2}$ The strand focuses on music education provision in Australian Early Childhood Education and entails a collective case study of seven Early Childhood Education centres in diverse settings. This paper reports one case, identified as "Exceeding National Quality Standard". The case-study approach is instrumental in purpose as it seeks to understand a phenomenon, "music education provision", within a specific case, an Australian Early Childhood Education centre (cf. Stake, 2008). Data generation methods and techniques included: two full days of observation in the Centre, and interviews conducted with the Director (1), Lead Educators (4), and Parents (3).

\section{Case Description}

The Centre is located in a suburb of Brisbane (Queensland), population 16,830, with a median age of 34 years. Of this population, $46.7 \%$ were born in Australia, $49 \%$ speak English only, and $23 \%$ are employed as "Professionals" (QPZM, 2015). The largest immigrant group in the com- munity is ethnic Chinese and is represented in the Centre enrolment. Unemployment is 7.8\% against a national average in 2015 of 6.2\% (Australian Bureau of Statistics, 2015). The Centre is one of a group of family-owned centres providing Early Childhood Education since 2003 and located across Brisbane to reflect the "character of the local communities" (Centre website, anonymised).

The Centre has an enrolment of 134 children aged 15 months to 5 years and is licensed to enrol 75 children per day. This figure is less than the national average and the Director describes the centre as "Boutique". The Centre hosts four rooms and conforms to the national standards concerning student:educator ratios ${ }^{3}$ (ACECQA, n.d.-a). A Lead Educator and Assistant are allocated per room and additional staff incorporated during intense activity (lunch, settling to sleep time, staff breaks), or as relief for planning and documentation responsibilities. For more detailed specifics in relation to individual rooms and lead educator qualifications, please refer to Table 1.

Table 1. Room and Lead Educator Qualifications Overview

\begin{tabular}{|l|l|l|l|}
\hline Name of Room & Age bracket & Number of Children & Lead Educator Qualifications \\
\hline Emu & $15-24$ months & 10 children & $\begin{array}{l}\text { Diploma in Early Childhood (completed in } \\
\text { Australia) }\end{array}$ \\
\hline Kangaroo & $24-36$ months & 16 children & $\begin{array}{l}\text { Certificate III in Early Childhood (completed in } \\
\text { Australia) and Bachelor of Education } \\
\text { (completed in Croatia) }\end{array}$ \\
\hline Echidna & $36-48$ months & 24 children & $\begin{array}{l}\text { Graduate Diploma of Early Childhood } \\
\text { (completed in New Zealand) and Bachelor of } \\
\text { Education (completed in India) }\end{array}$ \\
\hline
\end{tabular}




\begin{tabular}{|l|l|l|l|}
\hline Crocodile & $48-60$ months & 25 children & $\begin{array}{l}\text { Bachelor of Education and Early Childhood } \\
\text { (completed in Australia) }\end{array}$ \\
\hline
\end{tabular}

The Director's responsibilities include overseeing the daily operations and administration; management, leadership and guidance of staff; developing relationships with families and communities; and ensuring compliance with legislation and policy.

Lead Educators are identified as being in charge of a specific room, with responsibilities to: ensure the development of a curriculum that has clear goals and expectations for teaching and learning within their programme; provide mentorship and guidance to assistant staff; complete all documentation relevant to activities and events in the room including child reports; and build positive relationships with families and communities (ACECQA, n.d.-b).

\section{Methods and Techniques}

Following appropriate ethical permissions, extended observations were undertaken by one of the authors across all areas of the Centre (the four rooms in Table 1, plus outdoor play areas). Observations were documented through field notes and photography and sought to catalogue human and physical resources, identify the nature of musical provision within the Centre, and record children's incidental use of music. Interviews with the Director and Lead Educators probed: work history, training and qualifications; the participant's musical background; their beliefs about the role of music in children's lives; policy and music use in their programmes; and music within the Centre culture. Parent interviews explored music and its use in the home learning environment, beliefs about the role of music in their child's life, and perceptions and understanding of music and its use within their child's education and care.

Interview data were analysed to identify emerging themes using an analysis of narrative approach (Reissman, 2008). All authors undertook the analysis independently, meeting subsequently to review the emergent categories and confirm those identified. Observation data (recorded as field notes and photographs) were drawn upon to confirm/disconfirm those themes emerging in interview data. The analysis moved back and forth between observation, field notes and interview data to identify corroborating and/or anomalous data.

\section{Findings}

\section{Music as Value Adding Opportunity}

The Centre dedicates considerable human resources to the provision of music in several ways. The Centre engages external contractors to provide value adding opportunities through specialist extra-curricular activities. For no additional fee, all children receive weekly 30-minute Kodaly- based music classes and, fortnightly, the upper age-groups (Echidna and Crocodile) receive 60 minute Tiny Art classes. For an additional fee, children may participate in piano, dance, movement, exercise, sport and chess programmes (see Table 2). 
Two of the parents interviewed were also staff members at the Centre and provided additional insights into the role and importance of music-based value adding opportunities. They believed that having their child involved in a variety of music experiences and activities ensured a better quality education:

I think he probably had a better start in his education with being exposed to more musical things here. (Parent 1 )

They [have] all the facilities for the extracurricular and things, then they just offered that little bit more. Yeah, it's just to make her a more rounded person. I just know from studies that just learning music helps you in other things with your brain and it all helps, so why not. (Parent 2)

All educators emphasised the importance of the weekly Kodaly music classes (which they attended) as a form of ongoing informal professional development:

Look, I don't know much about policies in music and childcare, but what I really enjoy, we've got Kodaly music once a week here and ... the music teacher always brings more resources than we've got, especially the musical instruments. And that half an hour, it's a pleasure to watch, because she's specially trained music teacher so she can do more than we do here. And children looking forward to spending that half an hour on Monday morning. It's nice.

Q: Does it give you ideas as well? Like do you get to see the classes?

A: Yes, I'm always staying here so I can actually learn if there is something. I love to learn. And then we can extend on it. When I saw her dancing with the special scarfs, I just make streamers and the following time we just dance with streamers. You can learn from whatever she does with the children. I can always extend on what we already know. (Lead Educator 2 interview)

The overall provision at the Centre contains a strong multi-arts approach to young children's learning which has the capacity to benefit both the children and the educators simultaneously.

Table 2: Centre extra-curricula program (core and options)

\begin{tabular}{|l|l|l|l|l|}
\hline Activity & Frequency & Cost & $\begin{array}{l}\text { TOTAL CHILDREN } \\
\text { PARTICIPATING }\end{array}$ & $\begin{array}{l}\text { TOTAL CENTRE } \\
\text { PARTICIPATION }\end{array}$ \\
\hline Kodaly & Weekly & Free & 75 & $100 \%$ \\
\hline Piano & Weekly & $\begin{array}{l}\$ 37 \\
\text { individual; } \\
\$ 17 \text { group }\end{array}$ & 7 & $9.33 \%$ \\
\hline Happy Feet & Twice a week & $\$ 10.50$ & 40 & $53.33 \%$ \\
\hline Dance Pointe & Weekly & $\$ 11.00$ & 9 & $12 \%$ \\
\hline Dance Along & Weekly & $\$ 11.00$ & 3 & $4 \%$ \\
\hline Tiny Art & Fortnightly & Free & 59 & $100 \%$ \\
\hline Tennis & Weekly & $\$ 11.00$ & 7 & $9.33 \%$ \\
\hline Ginger Sport & Weekly & $\$ 11.00$ & 5 & $6.67 \%$ \\
\hline Chess & Weekly & $\$ 11.00$ & 3 & $4 \%$ \\
\hline
\end{tabular}

\footnotetext{
${ }^{2}$ Based on daily enrolment rate of 75 children per day
} 


\section{High Value for Music}

All five participant educators reported that they valued music in both their personal and professional lives, and held strong beliefs concerning its importance in young children's learning and life. This may be attributed in part to the values of the Centre Owner, as identified by the Director (see below). Common responses from interview data concerning the educators' high value for music highlighted:

- music's use in addressing all five of the formal learning outcomes identified in the EYLF (DEEWR, 2009, p. 8), despite its absence in the official documentation;

- a policy imperative for music engagement and learning to be accessible for all children; and

- the promotion and use of music as both an activity in its own right and also as a valuable educational tool that promotes learning and engagement in other areas, addresses individual needs, modifies behaviour, supports pro-social skills and focused attention, and supports emotional engagement.

Educators drew parallels between their own and the children's experience of music in the Centre, and described the ways in which this helps inform professional practice:

All depends what kind of music as well. If I start listening to relaxing music, my body is settling down and my brain is just calm. And the same with the children. As they're getting up from their sleep, if I turn the music on they will go and sit at the tables, they will start doing quiet activities ... If I turn dancing music on ... They will start jumping. So I think the children already know what kind of music they're listening to and they will react to it spontaneously. (Lead Educator 2)

All educators provided numerous examples of how they had observed music assist children in their wider development, including literacy, numeracy, mood regulation, motor coordination, self-esteem and identity and social skills. Lead Educator 1 explains:

Yeah, I would say for children it's [music] definitely more educational, because they're learning so much through it. Like, through a lot of the songs that we sing to them, they're learning colours, they're learning to count, they're learning body parts, you know, lots. And especially for these guys, they're learning English as well, because it's not their first language, and when we sing to them we show a lot of gestures, so they can associate the words with the movements that we're doing as well. So, for these guys it's really educational, I think it's an awesome way to learn. (Lead Educator 1 interview)

The educators made suggestions on ways that music could be situated within the EYLF, with the Director observing:

I don't think music's really embedded in the EYLF at all. I think it really plays on the individual educator on how their background, what they came from, because there's not really a great deal of music in EYLF at all. I don't even think it really is even mentioned... I mean our owner's big on music, so that's why we do have those programmes here. I 
mean she's got [an] education background so maybe she has identified that there isn't any music in EYLF and that's why she has it.

Q: Do you see music address the EYLF outcomes in...?

A: Yeah, it can be adapted or moulded to them, yeah definitely. Back to building confidence or a sense of belonging, those sorts of things, can definitely be moulded to different-and because music can be with-it can be anything. You could be making playdough and singing the recipe, how you're making it. So, it could be incorporating that measuring and counting. It can be moulded, but it [the EYLF] doesn't actually... I think music should be embedded. (Director interview)

Nevertheless, whilst all the educators valued music in children's learning and development, few were experienced in music education, or alert to policy and resources that might guide their music practice. Most (see Table 3) had received minimal or no music instruction during their training, although they seemed aware of this deficit in their knowledge base, as Educator 2 commented "I mean I do love singing but I feel it's not enough".

Table 3: Educator's formal and informal music training and experience

\begin{tabular}{|l|l|l|}
\hline Position & $\begin{array}{l}\text { Music/Arts included in } \\
\text { training qualifications }\end{array}$ & Music experience and engagement \\
\hline Director & No & n/a \\
\hline Lead Educator 1 & No & Piano and dance \\
\hline Lead Educator 2 & No & Piano, flute, accordion and voice \\
\hline Lead Educator 3 & Yes - minimal & Voice? \\
\hline Lead Educator 4 & Yes & Dance and recorder \\
\hline
\end{tabular}

\section{Staff Professional Development}

The Centre provides non-compulsory, formal music-based continuing professional development (PD) opportunities for all staff. These consist of a Kodaly Training Course and an annual conference featuring music presentations for all Centres affiliated with the ownership group. The value of these is highlighted below:

So, we are getting lots of training and it's up to us to attend or not to, but it's always helpful to attend something because you're learning. It doesn't matter how old we are, we are still learning always something new. You always learn from people who know more about those things and it's up to you how much you absorb from them. (Lead Educator 1)

The benefits of providing music-based professional development opportunities were twofold: first, educators confirmed the experience to be an empowering one,

That pretty much clarified that most of our day is singing. It was really good. It gave them lots of ideas to walk away with. It was really empowering. Made you feel like, "I can do this". (Director) 
Second, Lead Educator 4, who is completing the Kodaly Training Course, notes that PD has created a significant shift in her understanding of the role of music in childhood development:

I think initially [I viewed music as] just music for the sake of music. But now doing that training it breaks it down a little bit more for me and it points out that it all does integrate into development areas and I think that's - I like music and I like singing and so that's why I do it, but then I also realise that I am teaching the children something while singing to them. I am building that bond with them, even singing the Bee Bee Bumblebee song, and building the children's confidence in singing back. (Lead Educator 4)

The Centre has invested in a cascade model of professional development in which one team member undertakes the formal Kodaly training and then mentors colleagues in the methods and techniques that she has learned. As the Director explains:

Kodaly training, yeah. The whole purpose of that was because-not so much here because the girls really do interact with Catherine, mainly because we're a smaller service, but a lot of the biggest services that we have it in tend to go, oh yippee, there's another teacher in the room, it's just time away. They're not really taking in anything that's been done because the whole purpose of having Kodaly music is that they take on what they are teaching and filter it down to everybody on every day, not just Monday. That's why they're choosing one person from each service to do this training to filter it back to the staff to go; well this is why we do it, it's not just to have an extra set of hands or some time out for someone else to take the lead, that there's actually a reason behind why we are doing it. (Director interview)

The impact on the Educator's music learning through the informal professional development that arises from attending the in-school Kodaly session led by a specialist is illustrated in the following:

Yeah, I've learned quite a few songs from her as well that aren't your traditional sort of nursery rhymes and things like that. Yeah, I've used them that I can see that they really enjoy them within the class. (Lead Educator 1)

These findings suggest that practice-based, sequential and sustained PD provides early childhood educators with opportunity to overcome deficits/gaps that may arise from training.

\section{Integrated music practices}

Music use was a deeply embedded practice across all rooms. Educators across all age groups used songs to signal transitions into new activities, or routines such as packing away, washing hands and moving to the mat. In the Crocodile room, children knew that, when Pharrell William's "Happy" started playing, they needed to pack away, understanding that the quicker they packed away, the more time they would have for dancing to the song.

Well I think especially with the age grouping that I work with [15 months to 2 years], like I spoke to you about, when we're changing and going into a new routine, like washing our hands, like how they react to music more than just saying "Alright guys, let's go wash our hands", if we sing our handwashing song, then they all get up, they're all 
happy, and they all know the song associates hand washing. We usually, we actually, we should have it on now, they keep it for rest times and things like that, putting on the relaxation music. And once they sort of start hearing that music they'll hop on their beds. (Lead Educator 1)

All educators used music to teach elements of the curriculum. In the younger rooms, this largely focused on language acquisition, with both educators dedicating time for singing children's songs (Wheels on the Bus, Baa Baa Black Sheep) prompting children to complete or alternate phrases, sing name songs (Bee Bee Bumble Bee), and songs with identifying objects and elements of the child's world (Heads and Shoulders). In the older children's rooms, these concepts continued, alongside a focus on numeracy through the inclusion of counting songs (Ten in the Bed) and increasingly complicated direction sequences (Bluebird Through My Window).

During these more formal learning/activity times, whilst music was largely educator-led, time was provided for child-led opportunities, by asking children to contribute suggestions of "favourite songs", or spontaneously responding to child input:

But of a morning, we often sing good morning to each other, whether or not it's like that "Hello, how are you? Hello" that song, or the "Good morning to the sun up in the sky". Do you want me to sing it? (Educator sings)

"Good morning to the sun up in the sky. Good morning to the birds as they fly on by. Good morning to the trees that grow so tall. Good morning to the nest where the possums rest. Good morning everyone."

So that's a nice one that you use for the first six months, and then we've moved on to the "Hello, how are you?", and they can go around and say their name in the circle... They know that then we say the acknowledgement of country and then if time's permitting on these crazy days, we've got a talking stick that goes around in the circle so everyone can have their say and then we'll transition off ... And then I do at times just have spontaneous singing with the children. If we're in the sandpit and we're doing digging and "This is the way we dig a hole, dig a hole..." Yeah, those sorts of things or up on the swings, there was two little Echidna children who weren't really talking that much but they were more than capable of talking. I think it was just a relationship building thing and it only took about two weeks but they enjoy coming up and swinging on the swings as we sing songs to each other. So ,it's like little bits and pieces throughout the day that we do singing. (Lead Educator 4)

During research observations, children were observed initiating and incorporating music into their free play. When this occurred prior to the day's "formal learning time", the Educator would incorporate their singing into the learning programme for the day. Likewise, songs that were introduced during "formal learning" were often taken up by children in subsequent free play. For example, the Echidna room used Old MacDonald to explore animal sounds. Afterwards, whilst children were playing with animal figurines, they sang the song spontaneously. The Educator built on this by singing which animals should be included in a farm under construction. More formal music-making was observed as children practised their end-of-year graduation songs. Children practised songs with accompanying actions in 
groups of four, whilst the Educator coached the children throughout in matters of projection, pronunciation and posture.

The role of music-making in early childhood workers' lives is often overlooked. In the following excerpt, Educator 4 highlights the ways in which interactive music-making with the children sustains her through some of the repetitive routines of the day, and provides another means of communicating with the children:

... I just think I get bored pushing the swings so and I'll even sing, "This is the way we push the swings" just to keep myself sane. But then if I start, often they'll join in and then they'll go "Can we sing this song?" Anthony's a big one for "Down by the Station". He loves that song so if we're out on the obstacle course and they're on the train then off we'll go with "Down by the Station" or "The Wheels on the Bus" or, yeah. Whatever they're playing, just stick a song in there because often, and I'm not sure if it is a cultural thing (referring to children from NESB [non-English speaking background]), but if you ask them a question, often they might not answer you. And I don't know if it's whether or not they don't understand and they can't comprehend and then speak back to me. So, I just sing them a song and they're happy to listen to me. Which is good. (Lead Educator 4)

Instances of receptive music experience were evident in all rooms, as the Centre has a sleep policy that states "relaxing music will be played to help the children relax and fall asleep". Whilst no specific music is outlined in this protocol, the music tends to be instrumental, often classical or world-music in genre. The use of receptive music outside of sleep time has become limited due to the director and staff 's interpretation and understanding of the national governmental regulations, particularly in relation to the concept of intentional teaching and scaffolding. In preparation for National Assessment, the staff have been directed that CDs/background music can only be used if it is "linked to our programme ... and an extension of a particular experience you are building on". As a result of this, the staff feel that spontaneous opportunities for receptive music, to create or sustain a mood or ambience while the children play, is no longer an option unless the children request the music or it is written into the programme ahead of time.

\section{Physical resources}

Each room is equipped with CD players and CD collections largely compiled by the Lead Educator. These include: children's music (Wiggles, Playschool and Hi-5); adult easy listening (Enya, André Rieu); instrumental/world music (traditional Celtic); and classically arranged lullaby compilations and rainforest sounds. The Crocodile Room contains a listening station for the children to directly interact with during free-play time. Within the older age-group rooms, there is a marked increase in the use of digital technology, ranging from interactive whiteboards with sound speakers to digital learning programmes such as Letterland. The Centre owns a modest collection of musical instruments, primarily untuned percussion instruments, such as maracas, tambourines, claves, and drums. However, the Emu and Kangaroo room also have access to a number of toy xylophones that are shared between the rooms and are used by educators during planned activities, or if a child requests musical instrument play. In addition to the age-group rooms, the Centre also contains a piano teaching studio and a dance teaching studio. 
Given the lack of instrumental resources, opportunities are taken to create found

instruments:

We make instruments using recycled items, our centre's really big on not so much purchasing materials, but actually making our own. So, making our own shakers using old bottles and the dried rice and pastas and things like that, which we've got on the shelves in the classrooms. (Lead Educator 1)

\section{Constraints and challenges}

Whilst the Centre presents as an environment with high values for music, strong support for music professional development opportunities for educators, and a commitment to music as a value-added opportunity for all (rather than a fee-for-service), a number of constraints and challenges were identified. First, participants identified a significant challenge in the policy stipulations concerning daily programme design in which music may only be used if it is explicitly planned for and documented.

A: I think music should be embedded. Like I said before, it's so stupid that we have to have a reason to play music. It has to be linked to our programme. It has to be an extension of something. Whether we're seeing [child]... singing to his friend about a song that he'd seen or heard on the weekend, that we can only play music for that day because [child] initiated that experience. I just think that's really silly. I was really shocked and I only found out about this a couple of weeks ago when we did the A and R because the girls have always played background music. Our area manager said to Lead Educator 1, have you got that on your programme today? She's like, no. [The Manager's] like, well turn it off. So, she had to turn it off.

Q: So what about at nap time, because I know there's...

A: They play relaxing music. That's actually in our sleep policy that relaxing music is played to help the children relax and fall asleep. But as far as activity time, it must be programmed. (Director)

This policy and its impact on the educators' planning is corroborated by a parent who comments: "It's just crap now because you have to have music as part of-if you're playing music, it's got to be planned as such, you can't just put music on" (Parent 1).

Second, participants commented on the perceived lack of music experience, engagement or valuing in the home environments of children and children's expectations of music:

The one challenge I used to find, and it probably happens at the beginning of every year, is that sometimes it's just me singing. And the children don't want to do it. It's not I think they don't want to join in. It's whether or not they don't have the confidence, or they don't have the language and they're just more than happy just to sit there. Even if that does happen there doesn't seem to be any behavioural issues, like I don't have anyone hitting each other, so I think they're still learning, even if it is me singing, but at the time it can be quite frustrating. I think well why can't you just sing the song I'm singing? Like "Ba Ba Black Sheep." We've been singing it for a long time now but maybe it is just that they need to gain their confidence within the room. That's probably one of my biggest challenges is them not singing. And I do think that I have got a great bunch of children. And that they are really well behaved and I think sometimes it frustrates me 
because sometimes they might not be having a good day and I just think why can't you just do it? But that's me got to adapt how I want them to do it or how I'm explaining it because they might not understand what I'm explaining. (Lead Educator 4)

Third, the lack of physical resources, including books, songs, recordings and culturally appropriate instruments for music-making, was identified as a key challenge in the Centre:

Definitely resources ... we do lack in, new songs, or cultural songs, those sorts of things. I guess the internet you can probably these days jump on, but we don't have a lot of musical instruments. The girls have often asked for different cultural backgrounded, traditional instruments that they would use. But yeah, I would say resources... (Director)

I would probably like to either have a keyboard or a guitar and actually know how to play it. I think keyboard's probably more my thing... So, when I am singing the songs maybe it just might give that little bit more excitement to it as opposed to just being a voice all the time. And probably knowing more things to do with the children, especially using the instruments because if you don't really know how to use them yourself, the kids just bang and make a whole lot of noise, so I think it's knowing how to use instruments and again, broadening the repertoire to know different songs to use the instruments with. What other changes would I make? I think that's probably it. (Lead Educator 4)

Finally, as an extension of the physical resources, educators particularly in the younger rooms identified a real challenge with the integration of digital technology on a number of fronts. Although the educators have access to resources such as CD players and CDs, the limitations of these devices are becoming increasingly evident in the face of new technology:

I think it would be really cool if we could just use iPod docks where we can just access a whole range of music, rather than using CDs a lot, because CDs last not very long in our class. They're always getting scratches... (Lead Educator 1)

Despite the identified need to start integrating technology within their everyday practice, Educators 1 and 2 highlight one of the major points of discrepancy between policy and practice which constrains them:

Well I was using the iPad and sometimes I turn music on, but I stopped. We're not allowed to use this. I don't know the reason. So mostly we listen to the CD player. (Lead Educator 2)

Just talking to you about the laptops in the room and the little iPads and that. We have used those as well through media production to actually show children some nursery rhymes and that with little cartoon characters. Just for a different way to listen to music and learn from music. And they find pretty exciting too. It's something that we're not really allowed to use a lot of the time, but if it's extended from parent input... We can watch a little clip of that. (Lead Educator 1)

\section{Discussion}


Music is valued in this Centre. First, provision is available to every child through specialised weekly music lessons. Significantly, this instruction provides informal PD opportunities for the Educators. Second, the Centre adds to its curriculum through providing additional music services for a fee. That parents value this is evidenced by $53 \%$ of children participating in "Happy Feet Fitness" - a fitness and music-based programme. Third, the Centre supports staff in music PD opportunities that extend their capacity to use music in the programme. And finally, the Centre fosters integrated music practices into the daily programme (notwithstanding the challenges of providing incidental background music). These values and opportunities are supported by the provision of physical resources to implement music learning opportunities. The implication of these findings is that quality music education can be provided for young children when music is valued, well resourced, and supported through ongoing PD opportunities for Educators.

These case findings should be considered against the larger context of early childhood education and care in Australia and internationally. Australia has one of the lowest participation rates in early learning, with just $18 \%$ of 3-year-olds enrolled in Early Childhood Education, compared with $74 \%$ on average across OECD nations (OECD, 2014, 2015). Given that this Centre is one of the $27 \%$ of the 15,417 registered providers that are identified as "Exceeding National Quality Standards" for Quality Area 1 (Educational Program and Practice) (ACECQA, 2016), we hypothesise that-despite official policy providing little specific guidance on early years music-high quality Centres are likely to evidence a variety of music opportunities inter- woven into their daily activities to support learning in music and through music. Nevertheless, a second hypothesis is that, if significant numbers of providers are not meeting the Quality Standards, then many pre-primary-aged Australian children have much less opportunity for effective and enriching music learning and engagement.

The 2016 report The state of early learning in Australia (Early Learning: Everyone Benefits, 2016) notes that one in five Australian children "are vulnerable in key areas of development. This rate increases to two in five for Aboriginal and Torres Strait islander children" (2016, p. 2 ), whilst noting the importance of improving "access to quality early learning that the research shows amplifies children's development" $(2016$, p. 2). In summary, the authors note:

Overall Australia remains behind the rest of the developed world in supporting access to quality early learning. While we have caught up in rankings to improve access to fouryear-olds, we are far behind comparable countries in terms of the participation of threeyear-olds in early childhood education, including the United Kingdom, New Zealand and Denmark. This is despite the causal relationship between attendance at early learning and later educational outcomes. $(2016$, p. 3)

It is a continuing paradox that, despite the steadily accumulating body of evidence that points to the vital role of music learning and engagement in young children's development, Australian policy and guidance on the wider value and provision of music in early learning and engagement is largely mute. This is somewhat surprising given that, from a wider international perspective, there is a general shared international concern to address issues of social exclusion and to nurture social cohesion (UN General Assembly, 2013; EC, 2013)policies that are also formally supported by the Australian Government (cf. Australian Institute of Family Studies, 2017). Research suggests that systematic engagement in music 
can play a significant role in social inclusion across the lifespan, including in childhood (Rinta, Purves, Welch, Stadler Elmer, \& Bissig, 2011; Welch, Himonides, Saunders, Papageorgi, \& Sarazin, 2014). As reported in the introduction, music also has a powerful impact on young children's intellectual and emotional development (Barrett, 2009, 2011,2016a, 2016b; Williams et al., 2015). Therefore, music should be an integral feature of policy and practice in the early years, both in its own right and also for its power to support young children's wider development at home and in(to) school.

\section{Funding}

This research was funded by the Australian Research Council grant (DP130102488) Being and becoming musical: Towards a cultural ecological model of early music development (Barrett, M. S. \& Welch, G. F.).

\section{Notes}

1. In 2009, the Council of Australian Governments (COAG) agreed to a National Early Childhood Development strategy leading to the signing of a National Partnership Agreement (ACECQA Annual Report, 2013-2014 Australian Government, 2018). As a result, the Child Care Act of 2002 was abolished and in 2012, the National Quality Framework (NQF) was instated to facilitate all parties working collectively towards a National Quality Agenda for Early Childhood Education and Care (NQAECE). Subsequent agreements make provision for universal access to early childhood education, most recently 2018 (Council of Australian Governments 2018).

2. Barrett, M. S. \& Welch, G. F. (2013-2015). Being and becoming musical: Toward a cultural ecological model of early musical development. Australian Research Council Discovery project DP130102488.

3. Student:educator ratios as outlined on ACECQA are as follows: 0-24 months - 1:4; 24-36 months - 1:5; 36 months $+-1: 11$

\section{References}

Ansari, D., König, J., Leask, M., \& Tokuhama-Espinosa, T. (2017). Developmental cognitive neuroscience: Implications for teachers' pedagogical knowledge. In S. Guerriero, S. (Ed.), Pedagogical knowledge and the changing nature of the teaching profession (pp. 195-222). Paris, France: OECD.

Australian Bureau of Statistics. (2015). 6202.0 - Labour Force, Australia, September 2015. Retrieved from http://www.abs.gov.au/ausstats/abs@.nsf/mf/6202.0

Australian Children's Education and Care Quality Authority (ACECQA). (2016). NQF Snapshot Q2 2016. Sydney, Australia: Author.

Australian Children's Education and Care Quality Authority (ACECQA). (n.d.-a). New educator to child ratios for education and care services 1 January 2016. Retrieved from https://www.acecqa.gov.au/nqf/educatorto-child-ratios

Australian Children's Education and Care Quality and Authority (ACECQA). (n.d.-b). The role of the educational leader - information sheet. Retrieved from http://files.acecqa.gov.au/files/Information_ Sheets/TheRoleOfTheEducationalLeader.pdf

Australian Institute of Family Studies. (2017). Social inclusion. Retrieved from https://aifs.gov.au/cfca/ topics/social-inclusion

Bainger, L. (2010). A music collaboration with early childhood teachers. Australian Journal of Music Education, 2, $17-27$. 
Ballantyne, J., \& Packer, J. (2004). Effectiveness of preservice music teacher education programs: Perceptions of early-career music teachers. Music Education Research, 6(3), 299-312.

Barrett, M. S. (2009). Sounding lives in and through music: A narrative inquiry of the "everyday" musical engagement of a young child. Journal of Early Childhood Research, 7(2), 115-134.

Barrett, M. S. (2011). Musical narratives: A study of a young child's identity work in and through music- making. Psychology of Music, 39(4), 403-423.

Barrett, M. S. (2012). Music learning and education in early childhood: An overview. In G. E. McPherson \& G. F. Welch (Eds.), Oxford handbook of music education (pp. 227-228). Oxford, UK: Oxford University Press.

Barrett, M. S. (2016a). Attending to "culture in the small": A narrative analysis of the role of play, thought, and music in young children's world-making. Research Studies in Music Education, 38(1), 41-54.

Barrett, M. S. (2016b). Laying the foundations for narrative identities in and through music. In R. MacDonald, D. Hargreaves \& D. Miell (Eds.), Handbook of musical identities. Oxford, UK: Oxford University Press.

Brown, E. D., Benedett, B., \& Armistead, M. E. (2010). Arts enrichment and school readiness for children at risk. Early Childhood Research Quarterly, 25, 112-124.

Brown, E. D., \& Sax, K. L. (2013). Arts enrichment and preschool emotions for low-income children at risk. Early Childhood Research Quarterly, 28, 337-346.

Callanan, M., Anderson, M., Haywood, S., Hudson, R., \& Speight, S. (2017). Study of early education and development: Good practice in early education. London, UK: DfE/NatCen Social Research.

Council of Australian Governments. (n.d.). National partnership agreement on the national quality agenda for early childhood education and care. Retrieved from http://files.acecqa.gov.au/files/NQF/nap_national_quality_agenda_early_childhood_education_care_sig nature.pdf

Council of Australian Governments. (2018). National partnership on universal access to early childhood education - 2018. Retrieved from http://www.federalfinancialrelations.gov.au/content/npa/education/ national-partnership/UAECE_with_all_signatures.pdf

Cultural Learning Alliance. (2017). Key research findings: The case for cultural learning. Retrieved from https://culturallearningalliance.org.uk/evidence/key-research-findings-the-case-for-cultural- learning/

Department of Education, Employment and Workplace Relations (DEEWR). (2009). Belonging, being \& becoming: The early years learning framework for Australia. Canberra, Australia: The Australian Government, Commonwealth of Australia. http://files.acecqa.gov.au/files/National-Quality- Framework-ResourcesKit/belonging_being_and_becoming_the_early_years_learning_frame- work_for_australia.pdf

Department of Education, Employment and Workplace Relations (DEEWR). (2010). Educators, belonging, being and becoming: The educators' guide to the early years learning framework for Australia. Canberra, Australia: The Australian Government, Commonwealth of Australia.

DeVries, P. (2005). Music-making in a childcare centre: A case study. Proceedings of the XXVIIth Annual Conference; Reviewing the Future (pp. 53-60). Melbourne, Australia: Australian Association for Research in Music Education.

DeVries, P. (2006). Being there: Creating music-making opportunities in a childcare centre. International Journal of Music Education, 24(3), 255-270.

Early Learning: Everyone Benefits. (2016). State of early learning in Australia report 2016. Canberra, Australia: Early Childhood Australia. 
EC. (2013). Social Europe: Current challenges and the way forward - Annual report of the Social Protection Committee (2012). Luxembourg: Publications Office of the European Union.

Garvis, S. (2012). Exploring current arts practice in kindergartens and preparatory classrooms. Australasian Journal of Early Childhood, 37(4), 86-93.

Gordon, R. L., Fehd, H. M., \& McCandliss, B. D. (2015). Does music training enhance literacy skills? A metaanalysis. Frontiers of Psychology: Auditory Cognitive Neuroscience. http://dx.doi.org/10.3389/ fpsyg.2015.01777

Hallam, S. (2015). The power of music: A research synthesis of the impact of actively making music on the intellectual, social and personal development of children and young people. Department of Culture, Communication and Media, UCL Institute of Education: Music Education Council and International Music Education Research Centre (iMERC).

Hennessy, S. (2000). Overcoming the red-feeling: The development of confidence to teach music in pri- mary school amongst student teachers. British Journal of Music Education, 17(2), 183-196.

Hetland, L. (2000). Learning to make music enhances spatial reasoning. Journal of Aesthetic Education, 34(3-4), 179-238.

Kim, H. K., \& Kemple, K. M. (2011). Is music an active developmental tool or simply a supplement? Early childhood preservice teachers' beliefs about music. Journal of Early Childhood Teacher Education, 32, 135-147.

Letts, R. (2015). Tertiary pre-service courses for primary school specialist music teachers. Music Trust of Australia. Retrieved from http://musicinaustralia.org.au/index.php?title=Tertiary_Pre-service_ Courses_for_Primary_School_Specialist_Music_Teachers

Long, M. (2014). "I can read further and there's more meaning while I read": An exploratory study investigating the impact of a rhythm-based music intervention on children's reading. Research Studies in Music Education, 36(1), 107-124.

McPherson, G. E. (2009). The role of parents in children's musical development. Psychology of Music, 37(1), 91110.

Mills, J. (1989). The generalist primary teacher of music: A problem of confidence. British Journal of Music Education, 6(2), 125-138.

Nyland, B., Acker, A., Ferris, J., \& Deans, J. (2015). Musical childhoods: Explorations in the pre-school years. Abingdon, UK: Routledge.

OECD. (2014). OECD Family database. Retrieved from www.oecd.org/social/family/database OECD. (2015). Education at a glance 2015: OECD Indicators. Retrieved from http://www.oecd.org/education/education-at-a-glance-2015.htm

Phillips, R. D., Gorton, R. L., Pinciotti, P., \& Sachdev, A. (2010). Promising findings on preschoolers' emergent literacy and school readiness in arts-integrated early childhood settings. Early Childhood Education Journal, 38(2), 111-122.

Portowitz, A., Lichtenstein, O., Egorova, L., \& Brand, E. (2009). Underlying mechanisms linking music education and cognitive modifiability. Research Studies in Music Education, 31, 107-129.

Putkinen, V., Tervaniemi, M., \& Huotilainnen, M. (2013). Informal musical activities are linked to auditory discrimination and attention in 2-3-year-old children: An event-related potential study. European Journal of Neuroscience, 37(4), 654-661. 
QPZM. (2015). Sunnybank Hills demographics (QLD) local stats. Retrieved from http://sunnybank-hills. localstats.com.au/demographics/qld/brisbane/southern-suburbs/sunnybank-hills

Reissman, C. K. (2008). Narrative methods for the human sciences. Thousand Oaks, CA: Sage. Rinta, T., Purves, R., Welch, G. F., Stadler Elmer, S., \& Bissig, R. (2011). Connections between children's feelings of social inclusion and their musical backgrounds. Journal of Social Inclusion 2(2), 34-57.

Roden, I., Grube, D., Bongard, S., \& Kreutz, G. (2014). Does music training enhance working memory performance? Findings from a quasi-experimental longitudinal study. Psychology of Music, 42, 284-298. Stake, R. E. (2008). Qualitative case studies. In N. K. Denzin \& Y. S. Lincoln (Eds.), Strategies of qualitative inquiry (3rd ed., pp. 119-150). Thousand Oaks, CA: Sage.

Stunell, G. (2006). The policy context of music in English Primary Schools: How politics didn't help music. Research Studies in Music Education, 26(2), 2-21.

Suthers, L. (2004). Music experience for toddlers in day-care centres. Australian Journal of Early Childhood, 29(4), 45-49.

Suthers, L. (2008). Early childhood music education in Australia: A snapshot. Arts Education Policy Review, 109(3), 55-61.

UN General Assembly. (2013). A life of dignity for all: Accelerating progress towards the Millennium Development Goals and advancing the United Nations development agenda beyond 2015: A Report of the SecretaryGeneral. New York, NY: United Nations. Retrieved from http://www.un.org/millenniumgoals/pdf/A\%20Life\%20of\%20Dignity\%20for\%20All.pdf

Wetter, O. E., Koerner, F., \& Schwaninger, A. (2009). Does musical training improve school performance? Instructional Science, 37, 365-374.

Welch, G. F., \& Henley, J. (2014). Addressing the challenges of teaching music by generalist schoolteachers. Revista da ABEM [Associacao Brasiliera de Educacao Musical], 22(32), 12-38.

Welch, G. F., Himonides, E., Saunders, J., Papageorgi, I., \& Sarazin, M. (2014). Singing and social inclusion. Frontiers in Psychology, 5, 803. doi: 10.3389/fpsyg.2014.00803

Winsler, A., Ducenne, L., \& Koury, A. (2011). Singing one's way to self-regulation: The role of early music and movement curricula and private speech. Early Education and Development, 22, 274-304.

Williams, K. E., Barrett, M. S., Welch, G. F., Abad, V., \& Broughton, M. (2015). Associations between early shared music activities in the home and later child outcomes: Findings from the Longitudinal Study of Australian Children. Early Childhood Research Quarterly, 31, 113-124.

\section{Author biographies}

Margaret S. Barrett is Professor and Head of the School of Music at The University of Queensland. She is the Founding Director of the Creative Collaboratorium at UQ and leads a team of researchers investigating the life and learning outcomes of music education and engagement across the lifespan. Her research (funded by the Australian Research Council) encompasses the pedagogies of creativity and expertise and early music learning and development. She has served as President of the International Society for Music Education (2012-2014), Chair of the World Alliance for Arts Education (2013-2015), and Chair of the Asia-Pacific Symposium for Music Education (2009-2011). Publications include Collaborative Creative Thought and Practice in Music (Ashgate, 2014) and contributions to the major handbooks of the discipline. She is currently editing the Oxford Handbook of Early Childhood Music Learning and Development (with Graham Welch, UCL) .

Libby Flynn is a Brisbane-based music therapist, researcher and musician who completed both her Masters training and her PhD through the University of Queensland. Her expertise in the field of music therapy is based 
within adult mental health and well-being with national and international publications spanning a diversity of topics including substance abuse, dissociative identity disorder, cognitive behavioural music therapy, music and well-being and research methodology. Libby currently works in numerous research roles and is involved in music and music therapy-based projects spanning the lifespan. Since 2012 Libby has held the position as National Chair of Ethics for the Australian Music Therapy Association.

Graham Welch, PhD, holds the UCL Institute of Education (formerly University of London) Established Chair of Music Education since 2001. He is a Past President of the International Society for Music Education (ISME) (20082014) and elected Chair of the internationally-based Society for Education, Music and Psychology Research (SEMPRE). He is a former member of the UK Arts and Humanities Research Council (AHRC) Review College for Music (2007-2015). Publications number approximately 350 and embrace musical development and music education, teacher education, the psychology of music, singing and voice science, and music in special education and disability. New publications in 2018 will include an updated Oxford Handbook of Music Education (five volumes) and the Oxford Handbook of Singing. He is also working with Margaret Barrett (University of Queensland) on the new Oxford Handbook of Early Childhood Music Learning and Development - He was Chair of the Paul Hamlyn Foundation National Working Group on music education in England (http://www.inspiremusic.org) from 2015-2017. 